\title{
Peningkatan Prestasi Belajar Matematik Dengan Pendekatan Guided Discovery Materi Satuan Debit Pada Siswa Kelas V1 SDN Kwangpati Kecamatan Kopang Kabupaten Lombok Tengah Tahun Pelajaran 2017/2018
}

\author{
Hi. Zohrah \\ Kepala SDN Kwangpati \\ Kecamatan Kopang Lombok Tengah
}

\begin{abstract}
Abstrak: Penerapan Metode Guide Discovery untuk meningkatkan hasil belajar Matematika Materi Debit pada siswa kelas VI SDN Kwangpati Kecamatan Kopang Kabupaten Lombok Tengah Tahun Pelajaran 2017 /2018. Rumusan masalah dalam penelitian ini adalah bagaimanakah Meningkatkan Hasil Belajar Matematika Materi Debit dengan Pendekatan Ingquiry pada Siswa Kelas VI SDN Kwangpati Kecamatan Kopang Kabupaten Lombok Tengah Tahun Pelajaran 2017 /2018?. Penelitian tindakan kelas dilaksanakan melalui dua siklus, yaitu siklus I, dan siklus II, tiap siklusnya ada empat tahapan yaitu: 1) Planning, 2) Acting, 3) Observing, dan 4) Reflecting. Jika dibandingkan kedua hasil belajar siswa tersebut maka perolehan nilai rata - rata pada siklus I sebesar 69,96 dan meningkat pada siklus II menjadi 82,42 terjadi peningkatan sebesar 12,46 poin , jumlah siswa yang tuntas belajar pada siklus I sebanyak 18 orang atau dengan persentase $69 \%$ kemudian pada siklus II jumlah siswa yang tuntas belajar sebanyak 24 orang atau persentase sebesar $92,30 \%$ meningkat sebesar 23 poin, kemudian siswa yang belum tuntas pada siklus I sebanyak 8 orang atau dengan perentase sebesar $31 \%$ belum tuntas pada siklus II sebanyak 2 orang atau sebesar $8 \%$ terjadi penurunan sebesar 23 poin. Maka dengan demikian dapat ditarik kesimpulan bahwa dengan menggunakan metode Guide Discovery dapat meningkatkan hasil belajar siswa materi debit pada siswa kelas VI SDN Kwangpati tahun pelajaran 2017 / 2018.
\end{abstract}

Kata Kunci: Metode guide Discovery Hasil belajar Matematika

\section{PENDAHULUAN}

Masa kini dan masa mendatang terjadi perubahan dan perkembanagan yang begitu cepat dan mendasar dalam berbagai aspek kehidupan, antara lain perkembangan dibidang sains, teknologi, sosial, budaya, pemerintahan dan pergaulan dunia. Keadaan ini menunjukkan bahwa keadaan sekarang dan mendatang penuh dengan tantangan dan persaingan.Untuk mampu bertahan hidup dan mamapu menghadapi tantangan, persaingan dan ketidak pastian, serta permasalahan pelik dan rumit, maka peserta didik perlu dibekali, pengetahuan, pengalaman, dan keterampilan yang sesuai dengan kebutuhan dan tuntutan kemajuan.
Pembelajaran merupakan suatu proses kegiatan yang melibatkan seseorang dalam upaya memperoleh pengetahuan, keterampilan, dan nilai-nilai positif dengan memanfaatkan berbagai sumber dan teknik untuk belajar. Mata pelajaran Matematika dapat dipandang sebagai mata pelajaran yang ampuh untuk mencapai disiplin mental. Menurut Sumiati; Matematika berdasarkan teori daya lebih banyak menekankan pada penyajian soal yang sulit dengan tujuan agar siswa terbiasa berfikir ( Sumiati dkk 2008;50)

Dalam proses belajar

Matematika, Sumiati, dkk (2008) menyatakan pentingnnya tekanan pada kemampuan peserta didik dalam berfikir intuitif dan analitik akan mencerdaskan 
peserta didik membuat prediksi dan trampil dalam menemukan pola (pattren) dan hubungan/keterkaitan (relations).

Matematika bagi sebagian peserta didik merupakan mata pelajaran yang sulit. Materi yang disajikan sulit dipahami, karena Matematika sebagai pengetahuan mempunyai ciri-ciri khusus antar lain abstrak, deduktif, konsisten, hierarkis,dan logis. Soedjadi (2006) menyatakan bahwa keabstrakan Matematika kerena objek dasarnya abstrak, yaitu fakta, konsep, operasi dan prinsip.Dari uraian tersebut maka peneliti menawarkaan alternatif pemecahan msalah dengan menggunakan metode Guided Discovery ( penemuan terbimbing ) untuk meningkatkan hasil belajar agar pembelajaran menjadi lebih bermakna Perlu ada "jembatan" yang dapat menghubungkan yang dapat menghubungkan keilmuan Matematika tetap terjaga dengan materi Matematika yang dianggap sulit agar lebih mudah dipahami.

Hal ini dapat dicermati dari hasil ulangan harian peserta didik materi satuan Debit ternyata masih banyak yang belum mencapai ketuntasan minimal yang telah ditetapkan sekolah dalam hal ini SDN kwangpati, Kecamatan Kopang Kabupaten Lombok Tengah untuk mata pelajaran Matematika yaitu 70 pada tahun pelajaran 2016/2017. Dari 26 orang siswa yang tuntas belajar 11 orang atau dengan persentase sebesar hanya sekitar $42 \%$, kemudian jumlah siswa yang belum tuntas sebanyak 15 orang atau dengan persentase sebesar 58\% atau belum mencapai nilai ketuntasan minimal KKM, dan ketuntasan klasikal yang dipersyaratkan sebesar $\geq 80 \%$.

Hal ini disebabkan karena penggunaan metode yang tidak sesuai dengan materi, tidak menggunakan alat peraga serta siswa tidak di libatkan langsung dalam penemuan konsep agar pembelajaran menjadi lebih bermakna,serta menggunakan pendekatan yang sesuai dengan materi yang akan diajarkan.
Berdasarkan uraian tersebut di atas maka guru selaku peneliti tertarik memilih judul " Meningkatkan Hasil Belajar Matematika Materi Satuan Debit dengan Metode Guided Discovery pada siswa kelas VI SDN kwangpati tahun pelajaran 2017/2018.".

\section{Rumusan Masalah}

Bertitik tolak dari latar belakang di atas, maka penulis merumuskan masalah “ Bagaimanakah Meningkatkan Hasil Belajar Matematika Materi Satuan Debit dengan Metode Guided Discovery pada siswa kelas VI SDN kwangpati tahun pelajaran 2017/2018.?

\section{Tujuan Penelitian}

Berpedoman pada latar belakang di atas maka penelitian ini mempunyai tujuan yang ingin dicapai, yaitu " Meningkatkan Hasil Belajar Matematika Materi Satuan Debit dengan Metode Guided Discovery pada siswa kelas VI SDN kwangpati tahun pelajaran 2017/2018.”.

\section{Manfaat Penelitian}

Dengan penerapan Metode Guided Discovery dapat meningkatkan Kemampuan Siswa dalam memahami materi satuan debit dan bagian dari upaya guru untuk merefleksi diri dalam kegiatan memperbaiki proses pembelajaran. Sehingga Menjadikan bahan ajar lebih menarik, dalam proses pembelajaran agar prestasi akademik pesereta didik semakin meningkat.

\section{LANDASAN TEORI}

\section{Kajian Tentang Hasil Belajar}

Hasil belajar seringkali digunakan sebagai ukuran untuk mengetahui seberapa jauh seseorang menguasai bahan yang sudah diajarkan. Untuk mengaktualisasikan hasil belajar tersebut diperlukan serangkaian pengukuran menggunakan alat evaluasi yang baik dan memenuhi syarat. Pengukuran demikian dimungkinkan karena pengukuran merupakan kegiatan ilmiah yang dapat diterapkan pada berbagai bidang termasuk pendidikan.

Hasil belajar dapat dijelaskan
dengan memahami dua kata yang 
membentuknya, yaitu "hasil" dan "belajar". Pengertian hasil (product) menunjuk pada suatu perolehan akibat dilakukannya suatu aktivitas atau proses yang mengakibatkan berubahnya input secara fungsional. Hasil produksi adalah perolehan yang didapat karena adannya kegiatan mengubah bahan (raw materials) menjadi barang jadi (finished goods). Hal yang sama berlaku untuk memberikan batasan bagi istilah hasil panen, hasil penjualan, hasil pembangunan, termasuk hasil belajar. Dalam siklus inputproses-hasil, hasil dapat dengan jelas dibedakan dengan input akibat perubahan oleh proses. Begitu pula dalam kegiatan belajar

mengajar, setelah mengalami belajar siswa berubah perilakunya disbanding sebelumnya (Purwanto,2013:44). Hasil belajar adalah pola-pola perbuatan, nilainilai, pengertian-pengertian, sikap-sikap, apresiasi dan keterampilan. Merujuk pemikiran Gagne, hasil belajar berupa (Agus Suprijono,2012:5-6). (1) Informasi verbal yaitu kapabilitas mengungkapkan pengetahuan dalam bentuk bahasa, baik lisan maupun tertulis, (2) Keterampilan intelektual yaitu kemampuan mempresentasikan konsep dan lambang, (3) Strategi kognitif yaitu kecakapan menyalurkan dan mengarahkan aktivitas kognitifnya sendiri,

Keterampilan motorik yaitu kemampuan melakukan serangkaian gerak jasmani dalam urusan dan koordinasi, sehingga terwujud otomatisme gerak jasmani, (5) Sikap adalah kemapuan menerima atau menolak objek berdasarkan penilaian terhadap objek tersebut.

Menurut Bloom hasil belajar mencakup kemampuan kognitif, afektif dan psikomotorik. Domain kognitif adalah knowledge (pengetahuan, ingatan), comprehension (pemahaman, menjelaskan, meringkas, contoh), application (menerapkan), analysis (menguraikan, menentukan hubungan), synthesis (mengorganisasikan, merencanakan, membentuk bangunan baru dan evaluation (menilai). Domain afektif adalah receiving (nilai), organization (organisasi), characterization (karakterisasi). Domain psikomotor meliputi initiatory, pre-routine, dan rountinized (Agus suprijono,2012:6-7).

Dalam hubungan dengan satuan pelajaran, ranah kognitif menjadi tujuan utama, yang menjadi tujuan utama pengajaran di SD, SMTP, dan di SMU pada umumnya adalah peningkatan kemampuan siswa dalam aspek kognitif.

\section{Faktor-Faktor yang mempengaruhi Belajar.}

Belajar merupakan aktivitas yang berlangsung melalui proses, dan proses tersebut adanya pengaruh dari luar baik secara positif maupun negatif akan berpengaruh terhadap hasil belajar. Sugihartono, dkk (2007: 76) menggolongkan faktor-faktor yang mempengaruhi hasil belajar menjadi 2 yaitu: (a) Faktor internal adalah faktor yang ada dalam diri individu yang sedang belajar(b) Faktor eksternal adalah faktor yang ada di luar individu.

Berdasarkan pendapat di atas mengenai faktor yang mempengaruhi hasil belajar, peneliti mengambil kesimpulan faktor-faktor tersebut sangat mempengaruhi hasil belajar. Oleh sebab itu, masing-masing faktor perlu diperhatikan agar proses pembelajaran dapat berhasil sesuai dengan tujuan pembelajaran yang telah ditentukan

\section{Hakikat Pembelajaran Matematika di SD}

$\begin{array}{cc}\text { Pembelajaran } & \text { Matematika } \\ \text { adalah proses pemberian } & \text { pengalaman }\end{array}$ belajar kepada peserta didik melalui serangkaian kegiatan yang terencana, sehingga peserta didik memperoleh kompetensi tentang bahan Matematika yang dipelajari.

Matematika sering dipandang sebagai suatu pelajaran yang sulit, sukar dipahami, tidak menyenangkan. Hal ini disebabkan karena abstarknya konsepkonsep yang ada dalam Matematika tersebut, oleh sebab iti guru dituntut untuk menyampaikan Matematika dengan hal-hal/penjelasan yang kokrit yang sesuai denan 
perkembanagn anak sekolah dasar sehinga tercapai kompetensi yang diharapkan.

Salah satu komponen yang menentukan ketercapain kompetensi adalah penggunaan strategi pembelajaran Matematika yang sesuai dengan (1) Topik yang sedang dibicarakan, (2) tingkat intlektual peserta didik, (3) prinsip dan teori belajar, (4) keterlibatan aktif peserta didik, (5) keterkaitan dengan kehidupan peserta didik sehari-hari, dan (6) Pengembanagan dan pemahaman penalaran matematis. (Gatot Muhsetyo 2014.1.8)

$$
\text { Berdasarkan hal yang }
$$

diuraiakan diatas maka materi pelajaran Matematika di tingkat sekolah dasar hendaknya disesuaikan dengan kemamapuan nalar siswa sekolah dasar, dimana materi-materi yang abstrak diupayakan untuk disajikan secara kongkrit ataupun semi abstrak. Sehingga pembelaajaran Matematika di sekolah dasar menjadi pembelajaran yang bermakna bagi peserta didik.

\section{Prinsi-prinsip dalam pengajaran Matematika}

Matematika yang diajarkan di Sekolah Dasar adalah bagian Matematika yang dipilih guna menumbuhkankembangkan kemampuan dan membentuk pribadi siswa yang mengacu pada perkembangan ilmu pengetahuan dan teknologi.Hal ini berarti bahwa penggunaan Matematika disekolah tidak dapat dipisahkan dari ciri - ciri yang dimiliki Matematika yaitu ,Memiliki obyek kajian yang abstrak, berpola pikir deduktif dan konsisten.

\section{Fungsi Pengajaran Matematika}

Fungsi pengajaran

Matematika yang diajarkan di tingkat pendidikan dasar adalah sebai salah satu unsur masukan instrumental yang dimiliki obyek dasar absrak dan berlandaskan kebenaran konsistensi yaitu kebenaran pernyataan tertentu didasarkan pada kebenaran- kebenaran terdahulu yang telah diterima dalam sistem proses belajar untuk mencapai tujuan pendidikan.

\section{Hal-hal yang harus dilaksanakan dalam pengajaran matematika}

Dalam melaksanakan kegiatan belajar mengajar guru hendaknya memilih dan menggunakan srategi yang melibatkan siswa secara aktif dalam belajar,baik secara mental fisik maupun sosial.

Pengajaran Matematika hendaknya disesuaikan dengan standar kompetensi dan kompetensi dasar serta tidak melupakan perkembangan fisik siswa.Dengan demikian diharapkan akan terdapat keserasian antara pengajaran yang menekankan pada pemahanan konsep dan pengajaran yang menekankan keterampilan menyelesaikan soal dan pemecahan masalah,

Pengajaran dimulai dari hal hal yang kongrit dilanjutkan kehal - hal yang absrak,dari hal - hal yang mudah ke hal yang sulit dan dari hal yang sederhana ke hal kompleks.

\section{Materi Kelas VI SD Tentang Satuan Debit}

Ruang lingkup Matematika dalam kurikulum KTSP 2006 pada kelas VI SD/MI meliputi aspek-aspek operasi hitung bilangan, pengukuran, geometri, dan pengolahan data. Secara umum debit dapat didepinisikan dengan bayak zat cair yang mengalir dalam waktu tertentu. Atau denagan kata lain besar kecilnya air yang mengalir persatuan waktu disebut debit (Masnun, dkk,2006; 28)

Banyak zat cair diukur dengan menggunakan satuan volume, sehingga debit satuan zat cair berkaitan dengan volume dan waktu hubungan ketiganya dapat di nyatakan sebagai berikut:

$$
\text { Debit }=\frac{\text { Volume }}{\text { waktu }}
$$

Satuan satuan volume; $\mathrm{mm}^{3}, \mathrm{dm}^{3}, \mathrm{~cm}^{3}, \mathrm{~m}^{3}$, liter dan sebagainya dengan menggunakan atuan waktu detik, menit atau jam maka satuan debit yang biasa kita gunakan adalah; $\mathrm{mm}^{3}, \underline{\mathrm{cm}^{3}}$, lite

$$
\text { Detik detik detik }
$$

dan sebagainya 


\section{Kajian Tentang Guided Discovery ( Penemuan terbimbing)}

Menurut Jerome Bruner “ penemuan adalah suatu proses, suatu jalan / cara dalam mendekati permasalahan bukannya suatu produk atau iten pengetahuan tertentu". Dengan demikian di dalam pandangan Bruner, belajar dengan penemuan adalah belajar untuk menemukan, dimana seorang siswa dapat mencari jalan pemecahan (Markaban, 2006:9).

Penemuan terbimbing adalah suatu kegiatan pembelajaran yang mana guru membimbing siswa-siswanya dengan menggunakan langkah-langkah yang sistematis sehingga mereka merasa menemukan sesuatu( Gatot Muhsetyo, 2014, 1.35). dalam penemua terebut siswa akan merasakan suatu kebanggaan tersendiri .

Agar siswa-siswa dapat mengetahui dan memahami proses penemuan mereka perlu dibimbing antara lain dengan menggunakan pengamatan dan pengukuran langsung atau diarahkan untuk mencari hubungan dalam wujud "pola" atau bekerja secara induktif berdasarkan fakta -fakta khusus untuk memperoleh aturan umum.

Langkah - langkah model pembelajaran penemuan terbimbing menurut Soedjadi (dalam Julie Susilowati, 2008:15 - 16), agar pelaksanaan model pembelajaran penemuan terbimbing itu berjalan dengan efektif, beberapa langkah yang harus ditempuh guru Matematika adalah sebagai berikut : (a) Merumuskan masalah yang akan diberikan kepada siswa dengan data secukupnya, (b) Dari data yang diberikan guru, siswa menyusun, memproses, mengorganisasikan dan menganalisis data., (c)Siswa menyusun konjektur ( prakiraan ) dari hasil analisis yang dilakukan., (d) Bila perlu, konjektur yang dibuat siswa diperiksa oleh guru, (e) Apabila telah diperoleh kepastian tentag kebenaran konjektur, maka konjektur sebaiknya diserahkan kepada siswa untuk menyusunnya, (e) Sesudah siswa menemukan apa yang dicari hendaknya guru menyediakan soal latihan / soal tambahan untuk memeriksa apakah penemuan itu benar.

Penemuan terbimbing menekankan pada bagaimana siswa sampai pada suatu jawaban yang sesuai dengan langkah-langkah penyelesaian setiap soal dan siswa dapat mengembangkan penyelesaian soal sesuai dengan konsep dan teknik yang telah ditetapkan

METODE PENELITIAN

Penelitian ini merupakan penelitian tindakan (action research), karena penelitian dilakukan untuk memecahkan masalah pembelajaran di kelas. Penelitian ini juga termasuk penelitian deskriptif, sebab menggambarkan bagaimana suatu teknik pembelajaran diterapkan dan bagaimana hasil yang diinginkan dapat dicapai.

Penelitian ini mengacu pada perbaikan pembelajaran yang berkesinambungan. Kemmis dan Taggart (2009:14) menyatakan bahwa model penelitian tindakan adalah berbentuk spiral. Tahapan penelitian tindakan pada suatu siklus meliputi perencanaan atau pelaksanaan observasi dan refleksi. Siklus ini berlanjut dan akan dihentikan jika sesuai dengan kebutuhan dan dirasa sudah cukup.

\section{Desain Penelitian}

Penelitian ini dirancang untuk dilakukan dalam tiga siklus. Menurut pengertiannya penelitian tindakan adalah penelitian tentang hal-hal yang terjadi dimasyarakat atau sekolompok sasaran, dan hasilnya langsung dapat dikenakan pada masyarakat yang bersangkutan (Arikunto, 2002:82). Ciri atau karakteristik utama dalam penelitian tindakan adalah adanya partisipasi dan kolaborasi antara peneliti dengan anggota kelompok sasaran

Sesuai dengan jenis penelitian yang dipilih, yaitu penelitian tindakan, maka penelitian ini menggunakan model penelitian tindakan dari Kemmis dan Taggart (2008:14), yaitu berbentuk spiral dari siklus yang satu ke siklus yang berikutnya. Setiap 
siklus meliputi planning (rencana), action (tindakan), observation (pengamatan), dan reflection (refleksi). Langkah pada siklus berikutnya adalah perncanaan yang sudah direvisi, tindakan, pengamatan, dan refleksi. Sebelum masuk pada siklus 1 dilakukan tindakan pendahuluan yang berupa identifikasi permasalahan. Siklus spiral dari tahap-tahap penelitian tindakan kelas dapat dilihat pada gambar berikut:

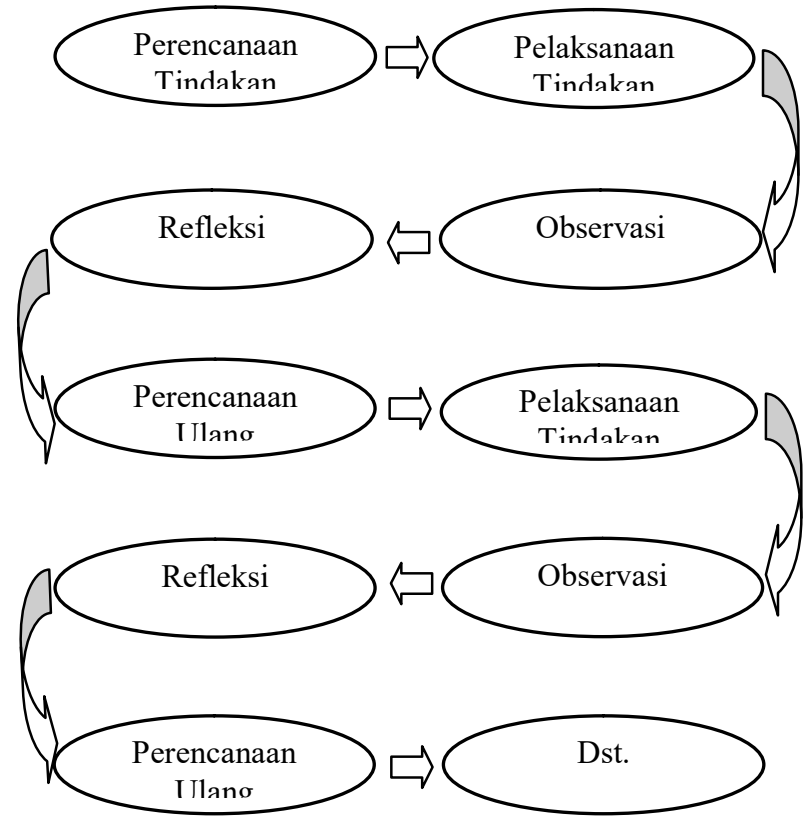

Gambar 3.1 Alur PTK.

Penelitian ini dilaksanakan dalam dua siklus/putaran. Observasi dibagi dalam tiga putaran, yaitu putaran 1, 2, dan 3, dimana masing putaran dikenai perlakuan yang sama (alur kegiatan yang sama) dan membahas satu sub pokok bahasan yang diakhiri dengan tes formatif di akhir masing putaran. Dibuat dalam tiga putaran dimaksudkan untuk memperbaiki sistem pengajaran yang telah dilaksanakan.

\section{Tempat dan Waktu Penelitian}

Penelitian ini bertempat di SDN Kwangpati Tahun Pelajaran 2017/2018 dan dilaksanakan pada bulan Juli sampai dengan bulan September tahun pelajaran 2017/2018.

Jurnal Pendidikan Mandala

\section{Subyek Penelitian}

Penelitian tindakan kelas ini menggunakan Subyek siswa-siswi Kelas VI SDN kwangpati Tahun Pelajaran 2017/2018 yang berjumlah 26 orang terdiri dari 14 orang laki- laki dan 12 perempuan .

\section{Prosedur Penelitian}

Penelitian ini dilaksanakan melalui 5 tahap, yaitu, (1) tahap perencanaan, (2) tahap persiapan, dan (3) tahap pelaksanaan, (4) tahap pengolahan data, dan (5) penyusunan Laporan.

\section{Teknik Analisis Data}

Untuk mengetahui keefektivan suatu metode dalam kegiatan pembelajaran perlu diadakan analisis data. Pada penelitian ini menggunakan teknik analisis dekriptif kualitatif, selama proses pembelajaran.

Untuk menganalisi tingkat keberhasilan atau peresentase keberhasilan siswa setelah proses belajar mengajar setiap siklus nya dilakukan dengan cara memberikan evaluasi berupa soal tes tertulis paa setiap akhir siklus .

Analisi ini dihitung dengan menggunakan statistik sederhana yaitu :Untuk menilai ulangan atau tes formatif Peneliti melakukan penjumlahan nilai yang diperoleh siswa, yang selanjutnya dibagi dengan jumlah siswa yang ada di kelas tersebut sehingga diperoleh rata-rata tes formatif dapat dirumuskan :

$\mathrm{X}=\frac{\sum x}{\sum \mathrm{N}}$

Dengan

$\overline{\mathrm{X}} \quad=$ Nilai rata-rata

$\sum \mathrm{X}=$ Jumla semua nilai siswa

$\sum \mathrm{N}=$ Jumlah siswa

\section{Untuk ketuntasan belajar}

Ada dua kategori ketuntasan belajar yaitu secara perorangan dan secara klasikal. Berdasarkan petunjuk pelaksanaan belajar mengajar kurikulum 20017 yaitu seorang siswa telah tuntas belajar bila telah mencapai skor $68 \%$ atau nilai 68 , dan kelas disebut tuntas belajar apa bila di kelas tersebut terdapat $85 \%$ yang telah mencapai 
daya serap lebih dari atau sama dengan $85 \%$.

( Kurikulum SDN kwangpati 2017)

Untuk menghitung presentase

ketuntasan belajar digunakan rumus sebagai

berikut : $\quad \mathrm{P}=\frac{\Sigma x}{\Sigma \mathrm{N}} \times 100 \%$

Keterangan

$\mathrm{P} \quad=$ Prosentase ketuntasan kelas

$\sum \mathrm{X}=$ Jumla semua nilai siswa

$\sum \mathrm{N}=$ Jumlah siswa

HASIL PENELITIAN

Diskripsi Hasil Penelitian

Data penelitian yang diperoleh adalah data observasi berupa pengamatan pengelolaan belajar aktif dan pengamatan aktivitas siswa dan guru pada akhir pembelajaran, dan data tes formatif siswa pada setiap siklus. Data tes formatif untuk mengetahui peningkatan hasil belajar siswa setelah diterapkan metode penemuan terbimbing.

\section{Pembahasan Hasil Peneltian} Siklus I

Untuk memperoleh gambaran dari hail penelitian diperlukan data. Data tersebut adalah sejumlah fakta yang digunakan sebagai sumber atau masukan untuk menentukan kesimpulan yang diambil yang menjadi topik pengamatan adalah kegiatan siswa, Kegiatan guru dan hasil pembelajaran siswa pada mata pelajaran Matematika di kelas VI.

\section{Tahap perencanaan}

Pada tahap ini peneliti mempersiapkan perangkat pembelajaran yang terdiri dari Rencana Pelaksanaan Pembelajaran siklus 1, LKS, siklus 1, soal tes formatif siklus 1 dan alat-alat pengajaran yang mendukung.

\section{Tahap kegiatan dan pelaksanaan}

Pelaksanaan kegiatan belajar mengajar untuk siklus I dilaksanakan pada tanggal 1 Agustus 2017 di kelas dengan jumlah siswa 26 siswa. Dalam hal ini peneliti bertindak sebagai Pengajar sekaligus sebagai peneliti dengan dibantu oleh salah seorang guru sebagai pengamat. Adapun proses belajar mengajar mengacu pada Rencana Perbaikan,dan setelah selesai proses belajar mengajar maka diadakan evaluai pada akhir kegiatan sehingga diperoleh hasil dari 26 siswa, 18 siswa yang sudah tuntas belajar atau dengan persentase sebesar $69 \%$ dan siswa yang belum tuntas belajar sebanyak 8 orang atau dengan persentase sebesar $31 \%$ ketuntasan belajar baru mencapai $69 \%$ karena siswa yang memperoleh nilai rata rata 69,96 lebih kecil dari persentase ketuntasan yang dikehendaki yaitu sebesar $80 \%$. Hal ini disebabkan karena siswa masih merasa baru dan belum mengerti apa yang dimaksudkan dan digunakan guru dengan menerapkan metode belajar aktif model Penemuan terbimbing (Guded discocery), maka penelitian dilanjutkan kesiklus berikutnya yaitu siklus II.

\section{Refleksi}

Dalam pelaksanaan kegiatan belajar mengajar diperoleh informasi dari hasil pengamatan sebagai berikut: 1) Guru kurang baik dalam memotivasi siswa dan dalam menyampaikan tujuan pembelajaran, 2) Guru kurang baik dalam pengelolaan waktu, 3) Siswa kurang begitu antusias selama pembelajaran berlangsung, 4) Media pembelaajaran tidak digunakan secara maksimal.

\section{Refisi}

Pelaksanaan kegiatan belajar mengajar pada siklus I ini masih terdapat kekurangan, sehingga perlu adanya refisi untuk dilakukan pada siklus berikutnya; 1) Guru perlu lebih terampil dalam memotivasi siswa dan lebih jelas dalam menyampaikan tujuan pembelajaran. Dimana siswa diajak untuk terlibat langsung dalam setiap kegiatan yang akan dilakukan, 2) Guru perlu mendistribusikan waktu secara baik dengan menambahkan informasi-informasi yang dirasa perlu dan memberi catatan, 3) Guru memanfaatkan media pembelajaran semaksimal mungkin.

\section{Siklus II}

\section{Tahap perencanaan}

Pada tahap ini peneliti mempersiapkan perangkat pembelajaran yang terdiri dari Rencana Perbaikan Pembelajaran siklus II , LKS, 2, soal tes 
formatif 2 dan alat-alat pengajaran yang mendukung, persiapan pada tindakan siklus II tidak jauh berbeda dengan perencnaan pada siklus I.

\section{Tahap kegiatan dan pelaksanaan}

Pelaksanaan kegiatan belajar mengajar untuk siklus II dilaksanakan pada tanggal 15 Agustus 2017 di kelas dengan jumlah siswa 26 siswa. Dalam hal ini peneliti bertindak sebagai Pengajar sekaligus sebagai peneliti dengan dibantu oleh salah seorang guru senior. Adapun proses belajar mengajar mengacu pada Rencana Perbaikan Pembelajaran dengan memperhatikan revisi pada siklus I, sehingga kesalahan atau kekurangan pada siklus I tidak terulang lagi pada siklus 2 .

Dilaksanakan bersamaan dengan pelaksanaan belajar mengajar. Pada akhir proses belajar mengajar siswa diberi tes formatif 2 dengan tujuan untuk mengetahui tingkat keberhasilan siswa dalam proses belajar mengajar yang telah dilakukan. Instrumen yang digunakan adalah tes formatif 2. Adapun data hasil penelitian pada siklus 2 adalah sebagai berikut:

Dari hasil pengolahan nilai diperoleh nilai rata-rata hasil belajar siswa adalah 82,42 dan ketuntasan belajar mencapai $92 \%$ atau ada 24 siswa sudah tuntas belajar, dan jumlah siswa yang tidak tuntas sebanyak 2 orang atau dengan persentase sebesar $8 \%$, kemudian ketuntasan klasikal mencapai $92 \%$ maka dengan demikian ketuntasan klasikal yang dipersyaratkan sebesar $\geq 80 \%$ sudah tercapai dengan demikian semua indikator yang dipersyaratkan sudah terpenuhi maka penelitian ini dihentikan sampai pada siklus II.

\section{Refleksi}

Dalam pelaksanaan kegiatan belajar diperoleh informasi dari hasil pengamatan menunjukkan peningkatan hasil dan proses pembelajaran pada siklus II sudah mencapai ketuntasan 80\% secara klasikal ,maka penelitian ini dihentikan sampai pada siklus II.

Jurnal Pendidikan Mandala

\section{PEMBAHASAN}

Setelah diadakan penelitian pada siklus 1 masih belum menunjukkan hasil yang memuaskan, bahwa kemampuan siswa dalam memahami materi pembelajaran Matematika pada materi satuan debit masih belum mencapai KKM yang telah di tetapkan yaitu 70 untuk mata pelajaran Matematikan tahun pelajaran 2017/2018. Hasil belajar siswa terhadap materi pelajaran satuan debit belum maksimal dari hasil tes di peroleh 18 siswa yang sudah tuntas belajar atau dengan persentase sebesar $69 \%$ dan siswa yang belum tuntas belajar sebanyak 8 orang atau dengan persentase sebesar $31 \%$ ketuntasan belajar baru mencapai $69 \%$ karena siswa yang memperoleh nilai rata - rata 69,96 lebih kecil dari persentase ketuntasan yang dikehendaki yaitu sebesar $80 \%$. Hal ini disebabkan karena siswa masih merasa baru dan belum mengerti apa yang dimaksudkan dan digunakan guru dengan menerapkan metode belajar aktif model Penemuan terbimbing ( Guded discocery), maka penelitian dilanjutkan kesiklus berikutnya yaitu siklus II.

Dari tabel di atas diperoleh nilai rata-rata hasil belajar siswa adalah 82,42 dan ketuntasan belajar mencapai $92 \%$ atau ada 24 siswa sudah tuntas belajar, dan jumlah siswa yang tidak tuntas sebanyak 2 orang atau dengan persentase sebesar $8 \%$, kemudian ketuntasan klasikal mencapai 92 $\%$ maka dengan demikian ketuntasan klasikal yang dipersyaratkan sebesar $\geq 80 \%$ sudah tercapai dengan demikian semua indikator yang dipersyaratkan sudah terpenuhi maka penelitian ini dihentikan sampai pada siklus II.

Jika dibandingkan kedua hasil belajar siswa tersebut maka perolehan nilai rata - rata pada siklus I sebesar 69,96 dan meningkat pada siklus II menjadi 82,42 terjadi peningkatan sebesar 12,46 poin , jumlah siswa yang tuntas belajar pada siklus I sebanyak 18 orang atau dengan persentase $69 \%$ kemudian pada siklus II jumlah siswa yang tuntas belajar sebanyak 24 orang atau persentase sebesar $92,30 \%$ meningkat 
sebesar 23 poin, kemudian siswa yang belum tuntas pada siklus I sebanyak 8 orang atau dengan perentase sebesar $31 \%$ belum tuntas pada siklus II sebanyak 2 orang atau sebesar $8 \%$ terjadi penurunan sebesar 23 poin.

Maka dengan demikian dapat ditarik kesimpulan bahwa dengan menggunakan metode Guide Discovery dapat meningkatkan hasil belajar siswa materi debit pada siswa kelas VI SDN Kwangpati tahun pelajaran 2017 / 2018.

\section{KESIMPULAN}

Penelitian ini menggunakan penelitian tindakan kelas, dengan dua siklus, Hasil penelitian melalui pendekatan penemuan terbimbing (guide discovery) dapat meningkatkan hasil belajar siswa pada materi satuan debit. Peningkatan hasil pembelajaran ditunjukkan dengan peningkatan hasil belajar dari siklus I ke siklus II menunjukkan hasil yang cukup signifikan.

Jika dibandingkan kedua hasil belajar siswa tersebut maka perolehan nilai rata - rata pada siklus I sebesar 69,96 dan meningkat pada siklus II menjadi 82,42 terjadi peningkatan sebesar 12,46 poin , jumlah siswa yang tuntas belajar pada siklus I sebanyak 18 orang atau dengan persentase $69 \%$ kemudian pada siklus II jumlah siswa yang tuntas belajar sebanyak 24 orang atau persentase sebesar 92,30\% meningkat sebesar 23 poin, kemudian siswa yang belum tuntas pada siklus I sebanyak 8 orang atau dengan perentase sebesar $31 \%$ belum tuntas pada siklus II sebanyak 2 orang atau sebesar $8 \%$ terjadi penurunan sebesar 23 poin.

Maka dengan demikian dapat ditarik kesimpulan bahwa dengan menggunakan metode Guide Discovery dapat meningkatkan hasil belajar siswa materi debit pada siswa kelas VI SDN Kwangpati tahun pelajaran 2017 / 2018.

\section{DAFTAR PUSTAKA}

Antonius Cahya Prihandoko. (2006). Memahami konsep matematika secara benar dan menyajikannya dengan menarik. Jakarta: Depdiknas Dirjen Dikti Direktorat Ketenagaan.

Arif Rohman. (2009). Memahami Pendidikan \& Ilmu Pendidikan. Yogyakarta: Laksbang Mediatama.

Ariyadi Wijaya. (2012). Pembelajaran

Matematika Realisik. Yogyakarta:

Graha Ilmu.

Daitin Tarigan. (2006). Pembelajaran Matematika Realistik. Jakarta:

Depdiknas Dwi Siswoyo, dkk. (2007).

Ilmu Pendidikan. Yogyakarta: UNY Press.

John W. Santrock. (2010). Psikologi Pendidikan. Jakarta: Kencana.

KTSP. (2007).Kurikulum Tingkat Satuan Pendidikan. Jakarta: BP Cipta Jaya

Gatot MuhSetyo, dkk 20014. Pembelajaran Matematika di SD , PDGK.4406, Universitas terbuka . Banten Indonesia

Hasibuan ...........Proses Belajar Mengajar II, Malang:I .2008, Undang-Undang RI No 20 Tahun 2003 tentang Sisdiknas, Sinar Garfika

Mohammad Asrori, 2009. Psikologi pembelajaran, Wacana Prima

Ngalim Purwanto. (2006). Prinsip-prinsip dan Teknik Evaluasi Pengajaran. Bandung: Rosdakarya.

Nurul Zuhriah 2009 . Metodologo Penelitian Sosial dan Pendidikan , TeoriAplikasi, Sinar Garfika

www.gigapurbalingga.net] 27-11-2017 20.17Gglech620320294x64 2007, kurikulum SDN kwangpati, SDN kwangpati 